you bring to the table and express your enthusiasm for the position.

Jim Keene, CFA, founder of Atherton Consulting Group, has similar advice. "Do not reference unethical behavior at prior places of employment. There can be ambiguity around the line of ethi$\mathrm{cal} /$ unethical behavior, and it can lead to misunderstanding or interpretations by a new prospective employer. Frame any discussion around the decision to leave as a difference in core values between yourself and the firm that became apparent shortly before leaving. Direct the narrative in new prospective situations as a desire to match values and aspirations in an energizing and meaningful [way] at a new firm."

Career coach Robert Hellmann of Hellmann Career Consulting largely concurs with Klaibert, Liak, and Keene. Whatever your reason for moving on, you generally don't want to draw attention to it, he says. If a potential employer doesn't ask, don't feel obligated to bring up the circumstances. As he puts it, "Each situation requires a tailored response, but in general the strategy is to talk less, not more. And bring it back to how you can help them."

Ethical behavior exerts a powerful influence in the financial industry, whether it's on client relationships, investment objectives, or career management. It may be challenging, but the focus must remain on the value ethical behavior adds rather than its potentially negative influence.

If you are dealing with ethical issues in your career, whistleblowing, or the like, the CFA Institute Code of Ethics and Standards of Professional Conduct is an excellent reference. You might also consider seeking legal counsel.

Julia VanDeren is a career services representative at CFA Institute. This article was originally posted on Enterprising Investor (blogs.cfainstitute.org/investor).

\title{
Grappling with Tough Questions
}

\section{ARE YOU PREPARED TO PAY THE HIGH COST OF INTEGRITY?}

By Jennifer Simpson

Have you ever put extra energy into preparing for a big race, a big performance, or some other once-in-a-lifetime goal, only to be delayed by having to help others along? At work, have you ever been waylaid by requirements to stop and evaluate the implications for your client, your company, or the broader financial system? Where do you draw the line to determine when a responsibility is yours to bear versus someone else's problem?

In the 1983 article "The Parable of the Sadhu," Bowen McCoy, at the time a managing director at Morgan Stanley participating in a company-sponsored, experimental six-month sabbatical program, tells the story of his epic trip to Mt. Everest, during which he came face to face with his own humanity. Three groups of people from various countries were attempting the climb; though conditions were decent, they discovered a severely hypothermic sadhu (Hindu holy man) along their route. One group of climbers transported him down the mountain a bit, and another group bundled the sadhu using their outer layers and then went on their way. A third set fed him and pointed him in the right direction to the nearest town. But nobody was quite sure whether he survived, because they were more interested in their own survival and in their attempt to meet their goal of summiting.

McCoy and a friend on the trip debate the breakdown between the individual ethic and the corporate ethic. That day on Everest, says McCoy's friend, "no one person was willing to assume ultimate responsibility for the sadhu. Each was willing to do his bit just so long as it was not too inconvenient. When it got to be a bother, everyone just passed the buck to someone else and took off."

In finance and investing, this dilemma may also arise, whether in making investment decisions, structuring new products, or advising clients. The outcomes may affect individuals or may be as far-reaching as influencing the stability of the global financial system. Clients, employers, employees, and regulators may have competing needs and interests, but in the end, high-integrity leaders find a balance.

As a CFA charterholder, what would you have done if you were a part of the "Parable of the Sadhu" story? Envision yourself and the role you play in your clients' financial lives through this lens. Although your dilemmas may not involve choosing between life and death on the frozen face of Mt. Everest, there are important parallels in the challenges you face as a financial professional. The following principles from the CFA Institute Code of Ethics and Standards of Professional Conduct set forth important guideposts in this respect, serving as relevant touchpoints for when you come across sadhus in your practice and in your life:

- Place the integrity of the profession and the interests of clients above your own interests.

- Act with integrity, competence, and respect.

- Maintain and develop your professional competence.

Do you focus on the long term? Are you willing to compromise achieving your stretch goals to ensure the survival of the sadhus you encounter? How do you prepare your organization to deal with these issues when they arise and ensure that duty to client jibes with duty to employer?

We discuss these questions and more around our seminar tables in the Finance Leaders Fellowship. To learn more, visit www.aspeninstitute.org/flf.

Jennifer Simpson is the managing director of the Finance Leaders Fellowship at the Aspen Institute. 